\title{
開於1952年應用已完成科蔼研究工 作之成績於國民經濟中的計劃
}

\author{
-一院士 H. H. 阿爾托布列夫斯基在1951年 9 月 14 日
}

蘇聯科學院主席團會議上的報告

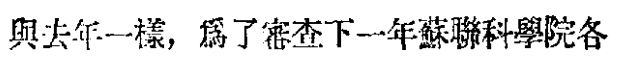
部各會已完成之科學研究工作的結果在國民經涴 中應用的計剖,科學院組織了主席團委員會。霞查 管用計劃時, 除了委員會的委員外，少有各部的院 士秘書械副秘書, 各部的學微秘書以及各所的領 導工作人是參加。

本年各部和各會的㤫用計劃比上一年絽的好

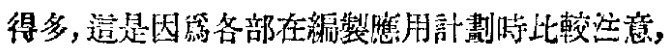

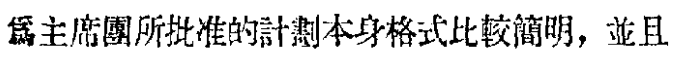
在1951年已絰辕累了這工作的縚䲆。

在去年於损出審查的 400 犁工作之中, 委員 會認䍃可以列入1951年度科學院許劃的只有 229 種: 在今年冬部、各會提 $44^{4} 360$ 種工作中, 就存 353

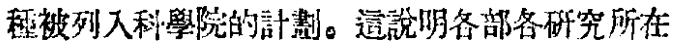

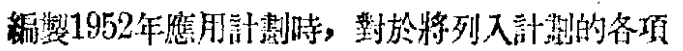
工作已經提畣了要求。

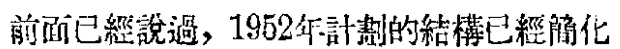

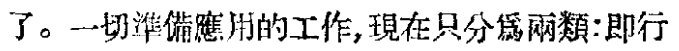

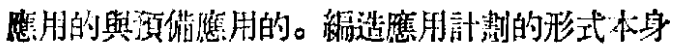

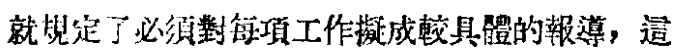

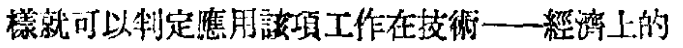
效用, 這程新形式也便利於檢查㗹用計劃䩚行的 请形，敛查不只在年終，即便在解决各倜偑別間題 的過犁中也可以曾行。

委員會很注意在工作應用中，劃分科學院各

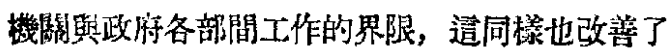
工作執行洔的检查。

除了害查萂聯科學院各部、各會的應用計劃， 委員會還行一㮔任務, 即是挑選計劃中對於间民 偨濟秘谷有重大意義的特別重要的工作項目, 建
議把這些工作列入國芜計割之中。

今年委員會建杽列入國管應用計割中的有 113 項工作，幾乎三倍於 1950 年所建議的，亚超 過 1951 年的建議一倍有餘。這 113 種工作,按部 與會分列如下:

\begin{tabular}{|c|c|}
\hline 物理-數學部 & 5 程 \\
\hline 化學部 & 6 種 \\
\hline 地質一地理學部 & 13 䅅 \\
\hline 生物學部 & 16 譒 \\
\hline 技衍科學部 & 28 種 \\
\hline 經濟學與法律學部 & 2 種 \\
\hline 生漟力研究會 & 2 種 \\
\hline 分院會議 & 41 程 \\
\hline
\end{tabular}

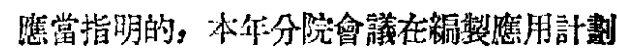

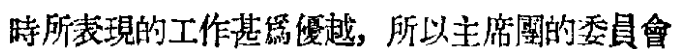
能於各分院的工作中建議列入國家計劃中的有 41 項之多。

各分院在應用計浗中提出的研究結果共有 270 項。在去年则嚾提出了 9 項。

列入鰠聯科學院㗹用計劃的總共有 353 種工

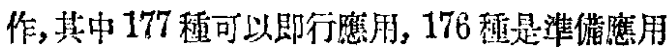
的。這些工作按部與會分列如下:

\begin{tabular}{|c|c|}
\hline 物理-数學部 & 34 稆 \\
\hline 化學部 & 84 墔 \\
\hline 地賢一地理學部 & 71 䧽 \\
\hline 生物學部 & 71 㖇 \\
\hline 技術學部 & 65 種 \\
\hline 經濟學與法律學部 & 17 種 \\
\hline 生产力研究會 & 14 踟 \\
\hline 分院會㦈 & 47 種 \\
\hline
\end{tabular}


引人注意的是遭些工作在按部分配中的不均 衡性。不能認舀滿意的是物理一數學部與化學部提

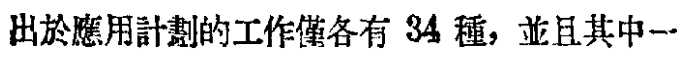
部分是在 1950 年與 1951 年已經列入過的。

若是把這雨部的科學研究工作計劃同它們的 應用計部比皎，不難使人相信，它們在應用方面的 工作是進行得非常地不够。例如, 在 1951 年化學 部的科學研究工作計澅中，㣹當完成研究的題目 是 117 项, 但是在 1952 年的礁用計劃中全體列 入的僅有 34 项，而且其中僅有 15 項是新的，所以 反胦在應用計剆中的嚾是一小部份該部在完成中 的科學研究工作的成果。

在物理一數學部和緸涳學與啮律學部的應用 計劃中也是同䧟一椂的情玟。

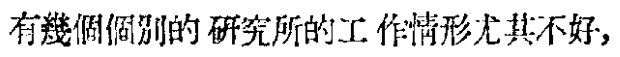

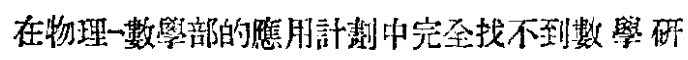
笁所工作結果的反陡, 踓然在1950年應用行劃中

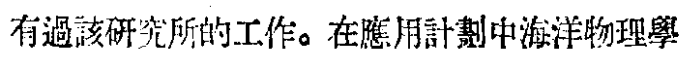
磁究所僅列入雨項完成的工作, 那樣大规模的組 織如物理學問通研究所與物理-枝矿科祭研究所, 每:所僅僅列入 4 項。

在化學部的應朋計劃中, 地質化學與分析化 學研究所, 水柔化學研究所並浔存提出一项工作, 只有一項工作是砥酸暨化學研究所提出的。化學 物理研究所與過氧化物研究室所提出来的工作也

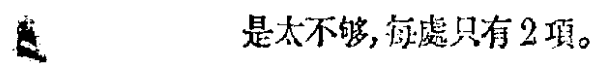

在地管一地理學部方面必須指啲的是漊土地

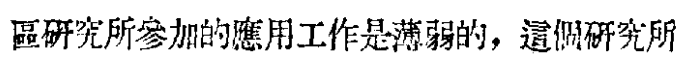

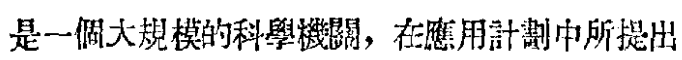
來的工作總共不過兩項, 只是在委員會指示以後, 才文補充了 2 项。

在生物學部的應用計劃中，完圶汥有反蜰遺 傅學研究所的工作, 踓然該所領導者李森科院士 的活動與圆民絰游的閵係是一般所共每的。即便 是在主席園委員會指活之後, 這種情形仍然沒有

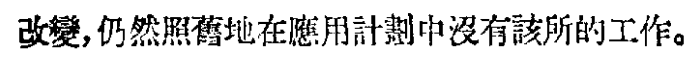

在硋部的應用計㓶中，生理學研究所只有一

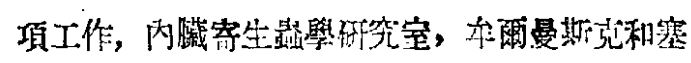
巴斯托波西研究站完圣沒有表現。

技術科學部在1952年應用計劃中所列入65项 工作，其中45项是從1950與1951年計割中過渡下

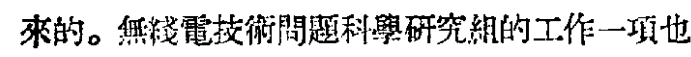

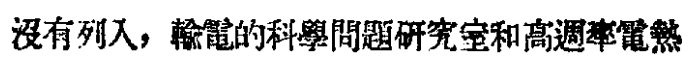
學研究空僅各列入一項。如此大規模的研究所如 冶金學研究所擬定應用的，樬共只有网項工作的 研究結果; 石酒研究所只計劃列入三項, 而且其 中的兩項是從 1939 年就開始焦用的; 颉力研究 所的工作非行的也不够, 列入應用計劃中的僅 有一项是 1951 年所完成的工作的成果，其他的 10 项都是已列人 1950 年與 1951 年應用計劃中 的。*

經濟學與法律學部對隹用研究所得結果的工 作做得更是不够，報告書的編定和傅迋照例的只 是鴿研究所管理處而計劃的, 所以應朋科學研究 結果於䨳践中的工作在其中幾乎是沼有考虑到。

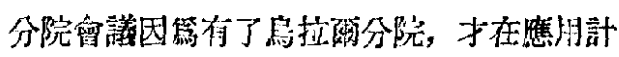
劃中有了工作項数的影著嘫扠，對於委員會沼有 提出一项有維果的工作的有:東西伯利丝分院，遠 果分院，卡絮利阿·芬闌分院，科米分院，摩酸達維:

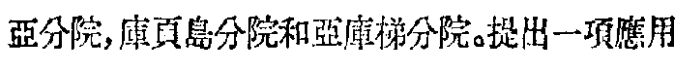
工作的有: 克里米亞分院，造格斯坦分院，吉爾吉 斯分院和阿爾漢格勤斯克站。

在 1952 年蘇聯科學院應用計丵中所列入的 科學研究成縝, 它們的應用都特是對於我國國民

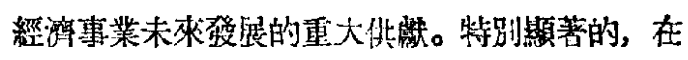
1952 年計劃中比皎充分地提出了部多理論上的 研究工作已經達到實際應用的階段。

聚門有關於共座主䉝偉大建設的題目特别地 仙很重要的地位。1952 年中將有40項研究工作的 成果直接雇朋於這種建設。

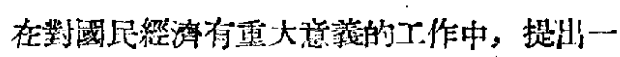
項作䍃例子，如物理一數學部中有一䅲工作，鍊鎆 過程高速控制的新方法，應用這倜方法可大量地 隇少筑品。

在化學部中應當指出的如：

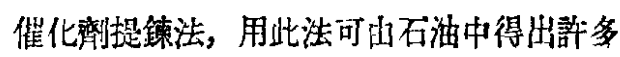
貴重物品;

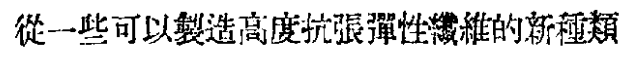
樹脂中獲得人造絲的方法;

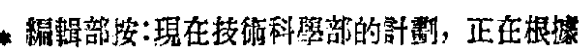

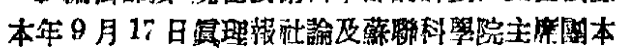
年 9 月 28 日關於技街科學部之科學活動的决到， 拈行修改中。 


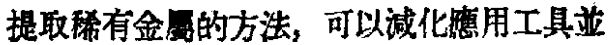
節省動力；由碳偂化合物加氧化氮使之氧化而得

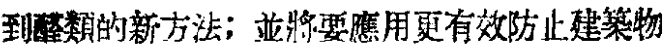
的侵触的新方法。

在地質一地理學部的應用計割中，以下的工

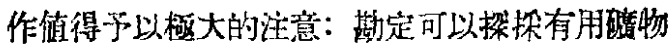
的首要區域，隹用新的方法探探並判定䝿重砟物 原料的䔾藏量，應用對於我國外海內海研究的結 果於國民經碎中，隹用航空方法於地質學研究上， 测量異海水位等工作。

生物學部計劃對於我国的改造自然給予很大

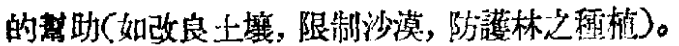

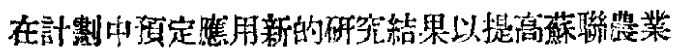
的效褒, 在維他命工業中應用新式装備, 各程大規

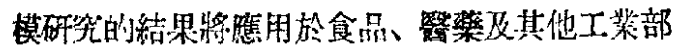
閏中。

如以前幾年的計劃一榡, 1952 年生物學部的

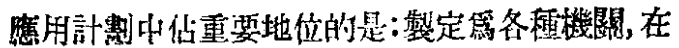
工作中日用必須的圖表、检素表和指南。特别是第 那些按着掌握有新水力工程建築地區的情况而擬 定措施的璣關。

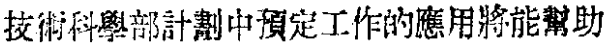
各技衍部門更進一步地得到改㬜, 增州機器和機

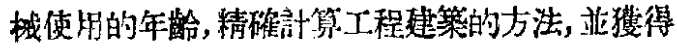
新的偠良質量的材料。

關於中央柔統和伏爾加河沿岸系統之動力統

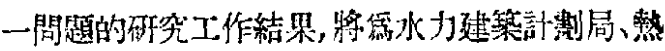

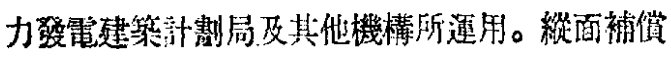
法的雇用將能增加輸電綫的容量。其他應用的罯

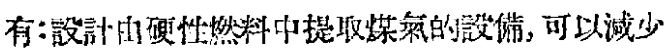
煤苝成杖的三分之一; 治煤的新方法，可以提高鼓

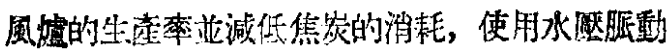
紀錄器，可以垶助研究各枆水力技衔建築型式對

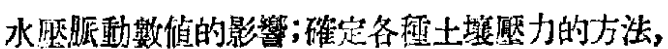
可以更精確地計算作用於支摚壁上的力。新的方 法可以確定各棰水力工程建築的最合理的傾斜 度。

有重大意義的，還有自预控制和自動調節的 聯合系統裴犆，它可以使生重過程的聯合自動化，
有新的可能性。

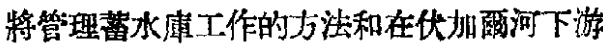
計算最大水量的精確方法，轉達水力建築計絜局。

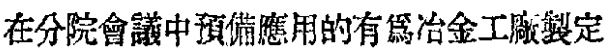
新策爈浊樣，可大大地減少金屬的損失，以新方法

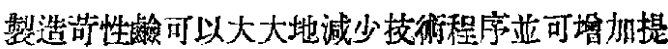

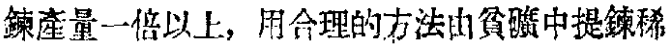

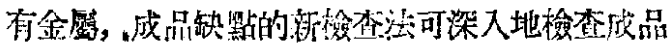
內部的缺點，以電化學的方法慗造器械，以代替资

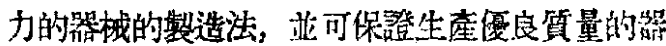
械。

在克里米严将要應用一種方注於一偑植物牛

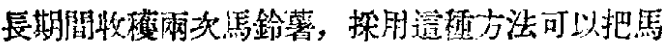
鈴薯的收㠛提高到現㭙產量的數倍。

以前偪說過, 1952 年蘚聯利學院科學研究工

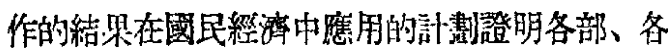
會議所進行的萑解工作已䌡改進了。

但是, 㩆然有顯著的改進, 這一工作仍然不能 適合国民經濟所提出的要求。1952 作仍應特别注

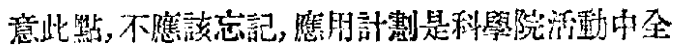
般㣔割的一偑重要部分，與科學研究工作的計割 是一樣重要的。

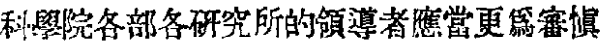

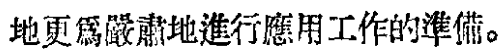

應用計劃忤行的成功, 只有在科學院與生產 機關閶嚴密合作的條件下才有可能的，只有在各 部各研究所領运者和研究員本人對於工作經常用 心的條件下才有可能的。

只有在科學院與政府各部配合工作的條件 下,科學研究結果的㤫用計劃才能成功地完成, 才 能在國是經濟中表現其必不可少的效力。

焦了使科學研究的結果更快地變成我們社會

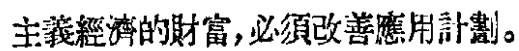

必須加强科學院與工業和㟽業的聯系，還要 提高科學在國民經濟中在我國共產主義建設中的 作用與意義。

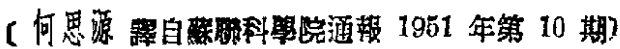

